\title{
HUBUNGAN EFEKTIVITAS KELEMBAGAAN PEMERINTAH DESA DENGAN TINGKAT KEBERDAYAAN PETANI BAWANG MERAH
}

\section{The Correlation of Village Goverment Institutional Effectiveness with The Empowerment Level of Shallot Farmers}

\author{
Fitri Amalia Rizki ${ }^{1}$ ), Lala M. Kolopaking dan Hana Indriana
}

Departemen Sains Komunikasi dan Pengembangan Masyarakat, Fakultas Ekologi Manusia, Institut Pertanian Bogor, Darmaga Bogor 16680, Indonesia

1) E-mail: $\underline{\text { fitriamaliarizki23@gmail.com; }}$

Diterima: 04-01-22 | Disetujui: 19-01-22 | Publikasi online: 21-01-22

\begin{abstract}
This research was aimed to analyze the correlation of village goverment institutional effectiveness with the empowerment level of shallot farmers in Larangan Village, Larangan Regency, Brebes District. The research was conducted with survey technique involving 40 respondents interviewed with structured questionnaires. The results of this research showed that the effectiveness of village goverment institutional did not correlate with the empowerment level of shallot farmers. This is because the village government was still focused on carrying out the government function and less focused on strengthening empowerment and agricultural development. The effectiveness of village government institutions is seen by shallots farmers in the medium category, while the empowerment level of shallot farmers was in the low category. Although, shallot farmers in Larangan Village still continue the shallot farming activities is influenced by the cultural value factors.
\end{abstract}

Key words: Farmers Empowerment, Institutional Effectiveness and Village Government

\begin{abstract}
ABSTRAK
Penelitian ini bertujuan menganalisis hubungan efektivitas kelembagaan pemerintah desa dengan tingkat keberdayakan petani bawang merah di Desa Larangan, Kecamatan Larangan, Kabupaten Brebes. Penelitian ini dilakukan dengan teknik survei dengan melibatkan 40 responden yang diwawancarai dengan daftar pertanyaan terstruktur. Hasil penelitian ini menunjukan bahwa efektivitas kelembagaan pemerintah desa tidak berkorelasi dengan tingkat keberdayaan petani. Hal ini akibat pemerintah desa masih berfokus pada menjalankan fungsi pemerintahan dan kurang berfokus pada penguatan pemberdayaan dan pembangunan pertanian. Efektivitas kelembagaan pemerintah desa dipandang oleh petani bawang merah berada pada kategori sedang, sedangkan tingkat keberdayaan petani bawang merah berada pada kategori rendah. Meskipun demikian, petani bawang merah di Desa Larangan masih tetap melanjutkan aktivitas bertani bawang merah yang dipengaruhi faktor nilai budaya.
\end{abstract}

Kata kunci : Efektivitas Kelembagaan, Keberdayaan Petani dan Pemerintah Desa. 


\section{PENDAHULUAN}

Indonesia adalah negara yang memiliki jumlah desa yang sangat banyak. Berdasarkan data Prodeskel Bina Pemdes ${ }^{1}$ jumlah desa dan kelurahan di Indonesia pada tahun 2018 sebanyak 83.404 desa yang tersebar di 34 provinsi. Apabila desa-desa tersebut dikelola oleh pemerintah pusat yang cenderung bersifat top-down dapat mengakibatkan program-program pembangunan yang dilakukan untuk desa menjadi tidak tepat saran dan tidak sesuai dengan kebutuhan masyarakat sehingga tidak berujung pada memberdayakan masyarakat (Mardikanto 2010). Hal ini sependapat dengan pernyataan Chavis (2001) yang dikutip oleh Ahmad dan Thalib (2015) yang menyatakan bahwa pemberdayaan dilakukan dengan memberikan dukungan kebijakan pada pemerintah lokal dalam memperluas, mencadangkan dan menyampaikan pertemuan yang efesien dan kesempatan memberdayakan.

Berdasarkan Undang-undang Nomor 6 tahun 2014 tentang Desa pemerintahan desa memiliki kewajiban dan hak penuh dalam mengembangkan masyarakat. Oleh karena itu, desa dituntut agar dapat melakukan pembangunan dengan baik yang dalam perencanaan, pelaksanaan hingga evaluasi melibatkan masyarakat. Dengan kata lain, pembangunan yang dilakukan oleh pemerintahan desa harus memberdayakan masyarakat. Pemberdayaan masyarakat oleh pemerintah desa dapat diupayakan melalui program pemberdayaan yang membantu menyangkut hal-hal pendanaan, peningkatan kemampuan sumberdaya manusia, dan kelembagaan (Sumodiningrat 1999).

Pemberdayaan masyarakat ini tidak terlepas dari peran serta sektor pertanian. Pemberdayaan masyarakat desa seharusnya lebih difokuskan kepada pemberdayaan masyarakat petani yang merupakan mayoritas penduduk desa, pemberdayaan ini dimaksudkan untuk meningkatkan kesejahteraan diri mereka dengan memberikan pembekalan dan pengetahuan agar dapat lebih maksimal menggali potensi diri mereka untuk menerapkan teknologi tepat guna sehingga produksi hasil pertanian dapat meningkat dan tercapai secara efektif efisien (Koho 2016).

Salah satu komoditas pertanian yang cukup penting bagi masyarakat Indonesia adalah bawang merah. Bawang merah merupakan salah satu komoditas sayuran unggulan yang sejak lama telah diusahakan oleh petani secara intensif. Berdasarkan Pusdatin Kementan 2016 konsumsi bawang merah cenderung meningkat dari tahun 2013-2015 pada tahun 2013 konsumsi bawang merah sebesar $2 \% \mathrm{~kg} / \mathrm{kapita} /$ tahun hingga tahun 2015 menjadi 2,71\% kg/kapita/tahun.

Produksi yang melimpah tersebut seringkali merugikan petani. Berdasarkan Pusdatin Kementan 2016 juga menyatakan bahwa keberadaan bawang merah yang cenderung musiman yang panennya cenderung serentak sehingga menyebabkan harga turun drastis. Penurunan harga yang sangat tinggi sering menjadi permasalahan pasar bawang merah (Widodo dan Rembulan 2010). Hal ini menunjukan tidak stabilnya harga bawang merah karena kurangnya ketersediaan bawang merah pada saat tidak musim panen yang kemudian berdampak pada harga bawang merah melonjak. Permasalahan ini mengakibatkan adanya tuntutan-tuntutan pada pemerintah agar turut membantu petani. Priyanto (2018) ${ }^{2}$ menyatakan petani bawang merah mendesak Bulog (Badan Urusan Logistik) untuk segera menyerap bawang merah petani dan menegaskan pada pemerintah untuk tidak mementingkan pengusaha atau tengkulak saja.

Hal ini memperlihatkan bagaimana efektivitas kelembagaan pemerintah dalam membantu memberdayakan petani khususnya pemerintah desa. Pemerintah desa memegang peranan yang sangat penting dalam menciptakan tata pemerintahan yang baik dan mendorong pemberdayaan masyarakat serta memberikan pelayanan pada masyarakat dalam pembentukan program -

${ }^{1}$ Prodeskel Bina Pemdes (Profil Desa dan Kelurahan Bina Pemerintahan Desa) adalah salah satu sistem informasi desa dan kelurahan yang diterbitkan oleh Kementerian Dalam Negeri Direktorat Jenderal Bina Pemerintahan Desa 2 Priyanto MA. 2018. "Petani Brebes Demo dan Sebar Bawang Merah Didepan Bulog". http://jateng.tribunnews.com/amp/2018/01/12/petani-brebes-demo-dan-sebar-bawang-merah-di-depan-bulog, 9 maret 2018, pukul 01.48 wib. 
program yang dijalankan sehingga dapat memandirikan dan menyejahterakan petani (Fauziyah 2015). Oleh karena itu, hal yang menjadi penting adalah menganalisis efektifitas kelembagan pemerintah desa dalam memberdayakan petani bawang merah.

\section{Rumusan Masalah}

Penelitian ini mencakup beberapa rumusan masalah yaitu (1) Bagaimanakah efektivitas kelembagaan pemerintah desa di Desa Larangan, Kecamatan Larangan, Kabupaten Brebes?; (2) Bagaimanakah tingkat keberdayaan petani bawang merah di Desa Larangan, Kecamatan Larangan, Kabupaten Brebes?; (3) Bagaimanakah hubungan efektivitas kelembagaan pemerintah desa dalam memberdayakan petani bawang merah di Desa Larangan , Kecamatan Larangan, Kabupaten Brebes?

\section{Tujuan Penelitian}

Penelitian ini bertujuan untuk: (1) Menganalisis efektivitas kelembagaan pemerintah desa di Desa Larangan, Kecamatan Larangan, Kabupaten Brebes; (2) Menganalisis tingkat keberdayaan petani bawang merah di di Desa Larangan , Kecamatan Larangan, Kabupaten Brebes; dan (3) Menganalisis hubungan efektivitas kelembagaan pemerintah desa dalam memberdayakan petani bawang merah di Desa Larangan, Kecamatan Larangan, Kabupaten Brebes.

\section{Kegunaan Penelitian}

Penelitian ini diharapkan dapat memberikan kegunaan bagi berbagai pihak, yaitu: (1) Bagi kalangan akademisi, penelitian ini diharapkan dapat menjadi salah satu sumber informasi dan pengetahuan mengenai hubungan efektivitas kelembagaan pemerintah desa dengan tingkat keberdayaan petani bawang merah. Penelitian ini juga diharapkan dapat menjadi acuan atau literatur untuk penelitian-penelitian selanjutnya; (2) Bagi pembuat kebijakan atau pihak pemerintah, penelitian ini diharapkan dapat menjadi salah satu rujukan mengenai peranan kelembagaan pemerintah desa yang efektif untuk memberdayakan petani bawang merah. Selain itu, penelitian ini diharapkan dapat membantu pemerintah mengevaluasi keberhasilan kelembagaaan pemerintah desa dalam menjalankan program pemberdayaan bagi petani; dan (3) Bagi masyarakat, penelitian ini diharapkan dapat menambah pengetahuan mengenai pentingnya peranan kelembagaan pemerintah desa dalam memberdayaan petani bawang merah.

\section{PENDEKATAN LAPANG}

\section{Metode Penelitian}

Penelitian ini menggunakan pendekatan kuantitatif yang dilengkapi dengan data kualitatif. Pendekatan kuantitatif dilakukan dengan menggunakan metode survei. Data kuantitatif diperoleh dari kuesioner yang dibagikan pada 40 responden, sedangkan untuk data kualitatif diperoleh dari wawancara mendalam kepada informan (perangkat desa, penyuluh Desa Larangan dan Ketua Kelompok tani) menggunakan panduan pertanyaan dan observasi.

\section{Lokasi dan Waktu Penelitian}

Penelitian ini dilaksanakan di Dukuh Temukerep, Desa Larangan, Kecamatan Larangan, Kabupaten Brebes, Provinsi Jawa Tengah. Pemilihan lokasi penelitian tersebut dilakukan dengan purposive (sengaja) dengan beberapa pertimbangan diantaranya, sebagai berikut: (1) Kabupaten Brebes merupakan sentra produksi bawang merah berskala nasional ${ }^{3}$; (2) Desa Larangan merupakan desa yang diresmikan oleh Presiden RI Joko Widodo sebagai desa percontohan implementasi pengembangan ekonomi kerakyatan pada tahun $2016^{4}$; (3) Desa

${ }^{3}$ https://ews.kemendag.go.id/bawangmerah/ProduksiBawangMerah.aspx

${ }^{4}$ Idris M. 2016 Apr 11. Di desa bawang Brebes, Jokowi akan resmikan program ekonomi rakyat. Detik.com [internet]. [Diunduh 2017 Feb 27]. Tersedia pada: https://finance.detik.com/berita-ekonomi-bisnis/d-3184399/di-desa-bawangbrebes-jokowi-akan-resmikan-program-ekonomi-rakyat 
Larangan merupakan desa binaan Dinas Pertanian dan Ketahanan Pangan dalam memberdayakan petani bawang merah; (4) Desa Larangan merupakan desa yang memiliki kontribusi produksi bawang merah yang cukup tinggi ${ }^{5}$.

\section{Teknik Penentuan Responden dan Informan}

Sumber data dari penelitian ini adalah responden dan informan. Responden dalam penelitian ini adalah petani bawang merah yang ada di Dukuh Temukerep, Desa Larangan, Kecamatan Larangan Kabupaten Brebes. Alasan memilih dukuh tersebut karena menurut pandangan Sekretaris Desa dan Penyuluh Desa Larangan petani pada dukuh ini merupakan petani yang paling maju di Desa Larangan. Informan dalam penelitian ini adalah pihak-pihak yang memberikan informasi mengenai kegiatan/program dari kelembagaan pemerintah desa dalam memberdayakan petani bawang. Informan dalam penelitian ini meliputi aparat desa, penyuluh, ketua kelompok tani dan masyarakat umum.

Unit analisis dari penelitian ini adalah individu petani bawang merah. Populasi dalam penelitian ini adalah seluruh petani bawang merah yang berada di Dukuh Temukerep, Desa Larangan. Kecamatan Larangan, Kabupaten Brebes. Berdasarkan informasi dari Sekretaris Desa Larangan jumlah petani di Dukuh Temukerep yaitu sebanyak 92 petani. dari jumlah populasi tersebut kemudian dipilih sebanyak 40 orang petani bawang merah di Dukuh Temukerep.

\section{Teknik Pengumpulan Data}

Data yang digunakan dalam penelitian ini terdiri dari data primer dan data sekunder. Data primer didapatkan langsung di lapangan melalui observasi dan wawancara menggunakan kuesioner kepada responden dan wawancara mendalam kepada informan. Data kualitatif yang bersumber dari data primer diperoleh melalui pengamatan langsung (observasi) dan wawancara mendalam. Observasi dilakukan dengan pengamatan kondisi petani bawang merah di desa binaan dan peran serta pemerintah desa untuk memberdayakan petani.

Sementara itu, data sekunder yang digunakan dalam penelitian ini diperoleh dari dokumen monografi Desa Larangan yang berasal dari Kantor Desa Larangan. Selain itu, data sekuender didapatkan melalui studi literatur untuk mendapatkan informasi pendukung terkait teori atau hasil penelitian sebelumnya yang berkaitan dengan topik penelitian yang diperoleh dari buku, jurnal penelitian, data monografi, hingga informasi tambahan lainnya yang diperoleh dari media cetak maupun elektronik.

\section{Teknik Pengolahan dan Analisis Data}

Data yang diperoleh dari penelitian ini berupa data kuantitatif dan data kualitatif. Data kuantitatif yang telah terkumpul selanjutnya dilakukan pengkodean data dan diolah menggunakan aplikasi Microsoft Excell 2010 dan SPSS for windows versi 16.0 sesuai masingmasing variabel. Pengujian variabel diuji dengan menggunakan uji korelasi Rank Spearman untuk melihat hubungan yang nyata antar variabel dengan data berbentuk ordinal dengan menggunakan SPSS for windows versi 16.0.

Menurut Usman dan Akbar (2006) korelasi merupakan salah satu teknik analisis statistik yang paling banyak digunakan oleh peneliti yang tertarik menghubungkan suatu peristiwa-peristiwa (penelitian sosial), hubungan yang dikenal oleh korelasi adalah hubungan yang searah saja (bukan timbal balik/sebab akibat). Besarnya angka korelasi disebut koefisien korelasi yang sering dilambangkan dengan lambang " $r$ ". Berikut adalah interpretasi dari nilai $r$ (koefisien korelasi):

${ }^{5}$ https://ews.kemendag.go.id/bawangmerah/ProduksiBawangMerah.aspx 
Tabel 1 Interpretasi nilai koefisien korelasi " $r$ "

\begin{tabular}{ccl}
\hline No & Nilai r & Kekuatan Hubungan \\
\hline 1 & 0 & Tidak berkorelasi \\
2 & $0,01-0,20$ & Sangat rendah \\
3 & $0,21-0,40$ & Rendah \\
4 & $0,41-0,60$ & Agak rendah \\
5 & $0,61-0,80$ & Cukup \\
6 & $0,81-0,99$ & Tinggi \\
7 & 1 & Sangat tinggi \\
\hline
\end{tabular}

Data kualitatif diperoleh dari hasil wawancara mendalam dan observasi kepada informan, kemudian dianalisis melalui tiga tahapan yaitu reduksi data, penyajian data dan verifikasi data.

\section{HASIL DAN PEMBAHASAN}

\section{Karakteristik Responden}

Responden dalam penelitian ini adalah petani bawang merah di Dukuh Temukerep, Desa Larangan, Kecamatan Larangan, Kabupaten Brebes, Jawa Tengah. Jumlah petani yang menjadi responden dalam penelitian ini sebanyak 40 orang. Petani yang menjadi responden tersebar pada wilayah RW 8, RW 9 dan RW 10. Petani responden dalam penelitian ini merupakan petani yang bergabung maupun tidak bergabung dengan kelompok tani di Dukuh Temukerep yakni Kelompok tani "Tani Mukti".

Responden dalam penelitian ini adalah individu petani bawang merah yang berjenis kelamin laki-laki dan perempuan. Jumlah antara laki-laki dan perempuan dalam penelitian ini cukup seimbang. Petani berjenis kelamin perempuan sebanyak 52,5 persen (21 orang dari 40 orang responden), sedangkan petani laki-laki sebanyak 47,5 persen (19 orang dari 40 orang responden). Jumlah yang seimbang ini dikarenakan dalam usahatani bawang merah di Desa Larangan terdapat pembagian peranan yang baik antara laki-laki dan perempuan. Petani lakilaki memiliki fisik dan stamina yang baik untuk mengelola ladang dan perempuan memiliki ketelitian dan kesabaran dalam merawat bawang merah.

Tabel 2 Jumlah dan persentase responden menurut umur

\begin{tabular}{ccc}
\hline Umur (tahun) & Jumlah (orang) & Persentase(\%) \\
\hline Dewasa awal & 0 & 0 \\
Dewasa menengah & $\mathbf{2 4}$ & $\mathbf{6 0}$ \\
Dewasa tua & 16 & 40 \\
\hline Total & 40 & 100 \\
\hline
\end{tabular}

Tabel diatas menunjukan bahwa umur petani responden berada pada kategori dewasa menengah (30-55 tahun) sebanyak 60 persen dan sebanyak 40 persen pada kategori umur dewasa tua. Hal ini menunjukan bahwa dunia pertanian kini hanya digeluti oleh orang tua dan terancam tidak ada generasi penerus. Hal ini dikarenakan berkurangnya minat pemuda dan lebih memilih pekerjaan lain. Pengalaman berusahatani petani bawang merah di Desa Larangan rata-rata sudah lama bergelut dalam dunia pertanian yaitu lebih dari 20 tahun. Rata-rata pengalaman ini terhitung sejak benar-benar memiliki lahan yang dikelola sendiri yang pada umumnya dimulai setelah berumah tangga.

Mayoritas petani memiliki luas lahan sekitar $875 \mathrm{~m} 2-1750 \mathrm{~m} 2$ atau istilah yang sering disebut petani sekitar yaitu 1/4 - 1/2 bau. "Bau" merupakan sebutan yang umum digunakan untuk mengukur satuan luas suatu lahan/tanah bagi masyarakat Desa Larangan. Ukuran bau tersebut apabila disetarakan sesuai standar SI (Sistem Internasional) setara dengan $7000 \mathrm{~m} 2$ atau 0,7 hektar. 
Status kepemilikan lahan petani bawang merah dapat berupa sendiri, nyewa maupun maro. Nyewa dalam bahasa Indonesia artinya "sewa", istilah ini digunakan petani penggarap yang cara membayarkan uang pada pemilik lahan dengan jumlah dan kurun waktu tertentu sesuai kesepakatan kedua belah pihak, setelah jangka waktu habis petani penggarap harus mengembalikan lahan yang disewa atau dapat juga disewa kembali dengan kesepakatan baru. Maro merupakan istilah jawa yang artinya "setengah-setengah" atau kata lain yang umum digunakan dalam bahasa Indonesia yaitu "garap".

\section{Efektivitas Kelembagaan Pemerintah Desa}

Efektivitas kelembagaan pemerintah desa adalah aktivitas atau upaya terpola yang dilakukan oleh pemerintah desa (kepala desa dan perangkat desa) untuk mencapai tujuan yang telah ditentukan dalam setiap kegiatan atau program dengan memaksimalkan sumberdaya yang ada. Efektivitas kelembagaan pemerintah desa ditentukan oleh beberapa indikator yaitu tingkat pengetahuan petani, tingkat partisipasi petani dan tingkat keeratan hubungan.

Tabel 3 Jumlah dan persentase responden berdasarkan efektivitas kelembagaan pemerintah desa

\begin{tabular}{lcc}
\hline $\begin{array}{c}\text { Efektivitas } \\
\text { Kelembagaan } \\
\text { Pemdes }\end{array}$ & $\begin{array}{c}\text { Jumlah } \\
\text { (orang) }\end{array}$ & $\begin{array}{c}\text { Persentase } \\
(\mathbf{\%})\end{array}$ \\
\hline Rendah & 15 & 37,5 \\
Sedang & $\mathbf{1 8}$ & $\mathbf{4 5}$ \\
Tinggi & 7 & 17,5 \\
\hline Total & 40 & 100 \\
\hline
\end{tabular}

Berdasarkan tabel 3, efektifitas kelembagaan pemerintah desa berada pada kategori sedang yaitu sebanyak 45 persen, namun demikian jumlah ini tidak memiliki perbedaan yang signifikan dengan jumlah pada kategori rendah yaitu sebanyak 37,5 persen. Hal ini dapat diartikan bahwa pemerintah desa (kepala desa dan perangkat desa) belum melakukan aktivitas atau upaya secara maksimal untuk mencapai tujuan tertentu (dalam hal ini untuk meningkatkan keberdayaan petani bawang merah) karena pemerintah desa masih berfokus pada fungsi pemerintahan dan belum berfokus pada pembangunan dan pemberdayaan pertanian.

Hal tersebut terlihat dari indikator tingkat pengetahuan petani yang masih rendah. Hal ini dapat diartikan bahwa petani bawang merah masih kurang pemahaman dan wawasan mengenai aktivitas pemerintah desa baik dalam segi program, kegiatan maupun pelayanan yang dilakukan oleh pemerintah desa. Hal ini dikarenakan program, kegiatan maupun pelayanan pemerintah desa tidak dibuat secara khusus untuk petani sehingga petani bawang merah tidak merasakan manfaat langsung dari aktivitas pemerintah desa.

Pada indikator tingkat partisipasi petani berada pada kategori sedang, karena petani bawang merah sudah mulai ikut serta dalam mengikuti program, kegiatan maupun pelayanan yang diadakan oleh pemerintah desa, meskipun belum secara sepenuhnya mengikuti pada setiap tahap partisipasi. Tahap partisispasi yang sebagian besar petani andil didalamnya yaitu tahap menikmati hasil, sedangkan pada tahap merencanakan, melaksanakan dan mengevaluasi petani belum dilibatkan secara maksimal.

Tingkat keeratan hubungan petani dengan pemerintah desa berada pada kategori sedang. Hal ini dapat diartikan bahwa petani bawang merah sudah memiliki kedekatan dengan dengan pemerintah desa yang dapat dilihat dari adanya rasa saling mendukung, saling ketergantungan dan saling percaya tetapi belum memiliki kedekatan dalam berkomunikasi (komunikasi dua arah). 


\section{Tingkat Keberdayaan Petani Bawang Merah}

Pemberdayaan merupakan proses memampukan, menguatkan dan memberi daya pada masyarakat sehingga mencapai peningkatan kemandirian dan kesejahteraan hidup masyarakat, sedangkan keberdayaan merupakan hasil dari proses pemberdayaan masyarakat yang memperlihatkan perubahan dan peningkatan kemampuan masyarakat. Indikator tingkat keberdayaan petani untuk penelitian ini yaitu tingkat kemampuan menghadapi hambatan, tingkat kemampuan mengelola hasil panen, tingkat kemampuan memasarkan produk, tingkat kemampuan kerjasama dan solidaritas dan tingkat keberlanjutan usaha.

Tabel 4 Jumlah dan persentase responden berdasarkan tingkat keberdayaan petani bawang merah

\begin{tabular}{lcc}
\hline $\begin{array}{c}\text { Tingkat } \\
\text { Keberdayaan } \\
\text { Petani }\end{array}$ & Jumlah (orang) & Persentase (\%) \\
\hline Rendah & $\mathbf{1 8}$ & $\mathbf{4 5}$ \\
Sedang & 8 & 20 \\
Tinggi & 14 & 35 \\
\hline Total & 40 & 100 \\
\hline
\end{tabular}

Berdasarkan tabel diatas, tingkat keberdayaan petani bawang merah berada pada kategori rendah yaitu sebanyak 45 persen. Hal ini dikarenakan sebagian besar indikator tingkat keberdayaan berada pada kategori rendah. Indikator tingkat kemampuan menghadapi hambatan termasuk kategori rendah, hal ini dikarenakan petani kesulitan dalam memenuhi permodalan yang dapat mempengaruhi kesediaan sarana produksi petanian khususnya bibit, pupuk dan obat-obatan. Pemenuhan yang sulit ini dikarenakan harga yang mahal dan harga hasil panen seringkali tidak sesuai dengan modal yang dikeluarkan.

Indikator tingkat kemampuan mengelola hasil panen berada pada kategori rendah dikarenakan petani kurang mampu melskuksn penanganan pascapanen yang apabila dilakukan dengan baik dapat meningkatkan kualitas dan harga jual. Misalnya, penanganan dalam melakukan sortasi dan grading serta pengemasan. Indikator tingkat kemampuan memasarkan produk juga terdapat pada kategori rendah, karena petani belum mampu melakukan pemasaran produk sesuai dengan unsur-unsur pemasaran. Kondisi ini dikarenakan petani yang belum memiliki variasi bentuk hasil panen yang dijual (masih menjual dalam bentuk bawang merah konsumsi/ bibit belum memiliki produk olahan). Selain itu juga dipengaruhi oleh sistem penjualan tebasan yang sangat bergantung pada tengkulak. Hal ini mempengaruhi lokasi dan cakupan wilayah penjualan hasil panen yang terbatas disekitar desa, belum ada petani yang menjual pada lingkup supermarket maupun produk kemasan.

Indikator tingkat kemampuan kerjasama dan solidaritas berada pada kategori rendah, kurangnya kerjasama petani dengan berbagai pihak untuk membantu mencukupi kebutuhan saprotan, modal, lahan maupun informasi pasar atau informasi budidaya. Selain itu, rendahnya kemampuan kerjasama dan solidaritas petani juga dipengaruhi oleh sebagian besar petani yang tidak bergabung dengan kelompok tani serta keberadaan kelompok tani yang kurang dirasakan manfaatnya bagi petani. Meskipun sebagian besar indikator berada pada kategori rendah, petani bawang merah di Desa Larangan masih tetap melanjutkan aktivitas bertani bawang merah. Hal ini dikarenakan petani memiliki ciri khas yang berbeda dengan petani bawang merah pada umumnya yaitu nilai budaya yang dianut oleh sebagian besar petani yang merasa bahwa petani akan bingung dan bosan apabila tidak bertani karena saat bertani selalu dapat mengisi waktu luang dan menjadikan hidup lebih produktif serta merasa sudah menjadi kebiasaan sejak lama sehingga apabila ditinggalkan merasa ada sesuatu hal yang kurang. 


\section{Hubungan Efektivitas Kelembagaan Pemerintah Desa dengan Tingkat Keberdayaan Petani Bawang Merah}

Efektivitas kelembagaan pemerintah desa adalah aktivitas atau upaya terpola yang dilakukan oleh pemerintah desa (kepala desa dan perangkat desa) untuk mencapai tujuan yang telah ditentukan dalam setiap kegiatan atau program dengan memaksimalkan sumberdaya yang ada. Efektivitas kelembagaan pemerintah desa ditentukan oleh beberapa indikator yaitu tingkat pengetahuan, tingkat partisipasi dan tingkat keeratan hubungan. Penjelasan rinci tentang hubungan tingkat partisipasi petani dengan tingkat keberdayaan petani terdapat pada tabel berikut.

Tabel 5 Nilai koefisien korelasi dan $p$-value terhadap efektivitas kelembagaan pemerintah desa dengan tingkat keberdayaan petani bawang merah

\begin{tabular}{ccc}
\hline & \multicolumn{2}{c}{ Tingkat Keberdayaan Petani Bawang Merah } \\
\cline { 2 - 3 } Variabel & Koefisien korelasi (r) & Sig. (2 tailed) \\
\hline $\begin{array}{c}\text { Efektifitas Kelembagaan } \\
\text { Peme-rintah Desa }\end{array}$ & 0,246 & 0,126 \\
\hline
\end{tabular}

Hasil uji korelasi Rank Spearman dengan menggunakan aplikasi SPSS 16.0 nilai Sig (2-tailed) atau nilai $p$-value yaitu sebesar 0,126 . Nilai ini berada diatas 0,05 sehingga tidak memenuhi kriteria pada taraf kepercayaan $95 \%$. Hal tersebut berarti hipotesis ditolak atau dengan kata lain tidak terdapat hubungan yang signifikan antara efektivitas kelembagaan pemerintah desa dengan tingkat keberdayaan petani bawang merah. Sementara itu, koefisien korelasi (r) pada hubungan dua variabel ini sebesar 0,246 . Hal ini dapat diartikan kekuatan hubungan yang sangat rendah. Meskipun demikian, karena nilai $p$-value > 0,05 dapat disimpulkan antara tingkat keeratan hubungan dan tingkat keberdayaan petani tidak memiliki hubungan yang signifikan.

Tidak adanya hubungan antara efektivitas kelembagaan pemerintah desa dengan tingkat keberdayaan petani diduga terdapat faktor lain yang menyebabkan keberlanjutan petani bawang merah terus berjalan hingga sekarang yaitu faktor nilai budaya petani yang dianut oleh sebagian besar petani yang merasa bahwa petani akan bingung dan bosan apabila tidak bertani karena saat bertani selalu dapat mengisi waktu luang dan menjadikan hidup lebih produktif serta merasa sudah menjadi kebiasaan sejak lama sehingga apabila ditinggalkan merasa ada sesuatu hal yang kurang. Hal ini didukung oleh kemampuan petani yang dapat membuka lapangan pekerjaan dengan mempekerjakan tenaga kerja non keluarga.

“...tani terus nggal diane soale wis sing gemiyen-gemiyen gaweane tani justru angger ora tani bingung arepan apa, maning-maning turu, njagong ngdeleng tipi. Angger lagi ana sing di tandurkan esuk-esuk gawean ning uamah beres terus mangkat sawah tilik ana bae pegaweane dadi misal modal laka ya tetep diusahakna bae...” (ALY, 60 tahun)

“...angger mangkat sawah kan ketemu karo kanca batir mbari lalar karo nggoleti uler mbari gluweh eben ora bosen ning umah. Toli angger ning umah baetah mba hawane pengin turu bae..." (WTR, 55 tahun)

“... bertani terus setiap hari karena sudah dari dulu pekerjaannya bertani justru kalau tidak bertani bingung mau apa, lagi-lagi tidur, duduk nonton televisi. Kalau sedang ada yang ditanam pagi-pagi pekerjaan rumah selesai dilanjut pekerjaan disawah, ada aja pekerjaannya jadi walaupun modalnya tidak ada tetap diusahakan aja..." (ALY, 60 tahun)

“...kalau berangkat kesawah itu bertemu teman-teman sembari merawat sawah dan membersihkan gulma ulat sembari bersenda gurau supaya tidak bosan dirumah. Terus kalau dirumah itu perasaan ingin tidur terus..." (WTR, 55 tahun) 
Pada dasarnya tidak terdapat hubungan antara efektivitas kelembagaan pemerintah desa dengan tingkat keberdayaan petani bawang merah, tetapi pemerintah desa dapat membantu mengupayakan keberdayaan petani. Berdasarkan hasil penelitian, petani masih merasa kesulitan dalam menghadapi hambatan, salah satunya dalam mengadapi kesulitan modal untuk menyediakan kebutuhan saprotan (Sarana Produksi Pertanian). Penyediaan modal ini dapat diupayakan pemerintah desa dalam memfasilitasi simpan pinjam bagi petani. Selain itu, petani juga masih kurang mampu mengelola hasil panen dan memasarkannya karena mayoritas petani menjual hasil panennya dengan sistem tebasan pada tengkulak. Hal ini berpengaruh pada kemampuan kerjasama dan solidaritas petani, petani belum banyak memiliki jaringan kerjasama. Kondisi ini dapat ditingkatkan dengan bantuan pemerintah desa melalui Badan Usaha Milik Desa (BUMDes) yang memfasilitasi simpan pinjam permodalan dan pemasaran hasil pertanian. Selain itu, untuk pemerintah desa juga dapat mengaktifkan kembali kelompo-kelompok tani dan mengawasi kegiatan kelompok tani agar keberdayaan petani dapat terus meningkat.

\section{KESIMPULAN}

Berdasarkan hasil penelitian yang telah dilakukan, maka dapat ditarik beberapa kesimpulan sebagai berikut: (1) Berdasarkan pandangan petani bawang merah, efektivitas kelembagaan pemerintah Desa Larangan, Kecamatan Larangan, Kabupaten Brebes berada pada kategori sedang, karena pemerintah desa sudah menjalankan fungsi pemerintahan, namun belum maksimal dalam menjalankan fungsi pembangunan dan pemberdayaan masyarakat khususnya pada pemberdayaan masyarakat petani bawang merah. Petani menyebutkan belum ada program untuk memberdayakan petani dari pemerintah desa; (2) Tingkat keberdayaan petani bawang merah di Desa Larangan, Kecamatan Larangan, Kabupaten Brebes masih berada pada kategori rendah dikarenakan pada indikator tingkat kemampuan menghadapi hambatan, tingkat kemampuan mengelola hasil panen, tingkat kemampuan memasarkan produk dan tingkat kemampuan kerjasama dan solidaritas berada pada kategori rendah. Hal ini dikarenakan dalam menjalani pertanian bawang merah belum ada yang mendampingi. Meskipun demikian, petani bawang merah di Desa Larangan masih tetap melanjutkan aktivitas bertani bawang merah. Hal ini dikarenakan petani memiliki ciri khas yang berbeda dengan petani bawang merah pada umumnya yaitu nilai budaya yang dianut oleh sebagian besar petani yang merasa bahwa petani akan bingung dan bosan mengisi aktivitas sehari-hari apabila tidak bertani. Selain itu, juga diperoleh gambaran mereka bahwa kegiatan bertani bawang merah menjadikan petani merasa lebih produktiF; dan (3) Tidak terdapat hubungan yang signifikan antara efektifitas kelembagaan pemerintah desa dengan tingkat keberdayaan petani bawang merah. Hal ini dikarenakan tidak terdapat program pemerintah desa yang secara khusus ditujukan untuk meningkatkan keberdayaan petani bawang merah. Pemerintah desa masih berfokus pada fungsi pemerintahan dan belum berfokus pada pembangunan dan pemberdayaan pertanian.

\section{Saran}

Berdasarkan hasil penelitian yang telah dilakukan, saran yang dapat diberikan dan dapat dijadikan masukan sebagai bahan pertimbangan bagi pihak-pihak terkait yaitu: (1) Sebaiknya pemerintah desa mulai membuat program-program untuk meningkatkan pemberdayaan dan pembangunan pertanian. Misalnya dengan membuat dan mengaktifkan Bumdes (Badan Usaha Milik Desa) yang dapat membantu petani bawang merah memenuhi permodalan, penyedia saprotan dan membantu pemasaran bawang merah; (2) Sebaiknya petani bawang merah meningkatkan kerjasama dengan pemerintah desa dan penyuluh untuk menyeimbangkan kegiatan usahatani bawang merah selain bekerjasama dengan pedagang saprotan dan tengkulak. Selain itu, juga dapat meningkatkan keaktifan dalam kelompok-kelompok tani yang kemudian dapat saling membantu dan bekerjasama dalam ekonomi produktif seperti membuat produk olahan dari bawang merah untuk menyiasati saat harga turun dan lebih tahan lama (tidak cepat busuk), produk ini juga dapat dijual melalui Bumdes; (3) Penelitian ini masih jauh dari kata 
sempurna, masih terdapat kekurangan dan kendala peneltian yaitu sulit mengukur efektivitas kelembagaan pemerintah desa menurut sudut pandang petani. Oleh karena itu, bagi peneliti selanjutnya yang akan meneliti dengan topik yang sama disarankan untuk melakukan pendekatan kualitatif secara lebih mendalam terkait hal tersebut.

\section{DAFTAR PUSTAKA}

[Permendagri] Peraturan Menteri Dalam Negeri. 2015. Susunan Organisasi dan Tata Kerja Pemerintah Desa [internet]. [diunduh 2018 Mar 12]. Tersedia pada: http://www.keuangandesa.com/wp-content/uploads/2015/02/Permendagri-Nomor-84Tahun-2015-Susunan-Organisasi-dan-Tata-Kerja-Pemerintah-Desa.pdf

[Pusdatin Kementan] Pusat Data dan Informasi Pertanian Kementrian Pertanian. 2016. Outlook Bawang Merah 2016 [internet].[diunduh 2018 Mar 05]. Tersedia pada: http://epublikasi.setjen.pertanian.go.id/download/file/301-outlook-bawang-merah-2016

[UU] Undang-undang republik indonesia Nomor 6 tahun 2014 tentang Desa pasal 1 ayat 1 [internet]. [diunduh 2017 Okt 10]. Tersedia pada: http://www.dpr.go.id/dokjdih/document/uu/UU 2014 6.pdf

Ahmad MS dan Tholib NBA. 2015. Empirical investigation of community empowerment and sustainable development: quantitatively improving qualitative model. Qual Quant [internet]. [diunduh 2017 Nov 24]; 49(2): 637-655. Tersedia pada: https://search.proquest.com/docview/1653052961/fulltextPDF/67ED53233CFE4EEAPQ/ 2 ? accountid $=32819$

Anantanyu S. 2011. Kelembagaan petani: peran dan strategi pengembangan kapasitasnya. SEPA [internet]. [diunduh 2018 Feb 22]: 7(2): 102-109. Tersedia pada: https://ejournal.unsrat.ac.id/index.php/politico/article/view/6723/6243

Ariyati SN dan Sjaf S. 2014. Efektivitas kelembagaan desa dalam praktik demokrasi di Desa Kelangdepok, Pemalang, Jawa Tengah. Jurnal Sodality: Jurnal Sosiologi Pedesaan [internet]. [diunduh 2017 Sep 25]; 2 (3): 233-244. Tersedia pada: http://id.portalgaruda.org/index.php? ref=browse $\&$ mod=viewarticle $\&$ article $=323789$

Budiani NW. 2012. Efektivitas program penanggulangan pengangguran Karang Taruna 'Eka Taruna Bhakti' Desa Sumerta Kelod Kecamatan Denpasar Timur Kota Denpasar. Jurnal Ekonomi dan Sosial INPUT [internet]. [diunduh 2018 Agu 19]; 2(1): 49-57. Tersedia pada: https://ojs.unud.ac.id/index.php/input/article/view/3191

Faini RN dan Ma'ruf MF. 2016. Efektivitas lembaga pemberdayaan masyarakat desa dalam mendukung pembangunan di Desa Kedunglumpang Kecamatan Mojoagung Kabupaten Jombang. Jurnal Kajian Otonomi Daerah [internet]. [diunduh 2017 Nov 23]; 1(1): 1-8. Tersedia http://jurnalmahasiswa.unesa.ac.id/index.php/publika/article/view/15068/19074

pada:

Firmansyah H. 2012. Tingkat keberdayaan masyarakat dalam program pemberdayaan masyarakat di Kota Banjarmasin dan Kabupaten Tanah Laut. Jurnal Agribisnis Perdesaan [internet]. [diunduh 2017 Des 17]; 2(1): 53-67. Tersedia pada: https://googleweblight.com/?lite_url=https://www.neliti.com/id/publications/9264/tingkat -keberdayaan-masyarakat-dalam-program-pemberdayaan-masyarakat-di-kotaban\&ei=PjxNEXU0\&lc=id-

ID\&s=1\&m=849\&host=www.google.co.id\&ts=1513549245\&sig=AOyes_Q6cmir6rVot W4r84pwb5WTO2CsPg 
Hapsari PA. 2017. Efektivitas program pemberdayaan masyarakat oleh pusat studi biofarmaka tropika [skripsi]. Bogor (ID): Institut Pertanian Bogor

Haryanto Y, Sumardjo, Amanah S dan Tjitropranoto P. 2017. Efektivitas peran penyuluh swadaya dalam pemberdayaan petani di Provinsi Jawa Barat. Jurnal Pengkajian dan Pengembangan Teknologi Pertanian [internet]. [diunduh 2018 Agu 11]; 20(2): 141-154. Tersedia pada: https://media.neliti.com/media/publications/229329-efektivitas-peranpenyuluh-swadaya-dalam-7ffb8d50.pdf

Ivancevich JM, Konopaske R, Matteson MT. 2007. Perilaku dan Manajemen Organisasi. Gina Gania. Jakarta (ID): Erlangga. Terjemahan dari: Behavioral and Organizational Management.

Kasmel A dan Andersen PT. 2011. Measurement of community empowerment in three community program in Rapla (Estonia). Int. J. Environ. Res. Public Health [internet]. [diunduh 2018 Sep 08]; 8:799-817. doi:10.3390/ijerph8030799. Tersedia pada: http://www.mdpi.com/1660-4601/8/3/799/pdf

Koho FCSG. 2016. Peran pemerintah desa dalam pemberdayaan masyarakat. Jurnal Eksekutif [internet]. [ diunduh 2018 Feb 20]; 1(7). Tersedia pada: https://ejournal.unsrat.ac.id/index.php/jurnaleksekutif/article/viewFile/7671/7237

Mardikanto T. 2010. Konsep-konsep Pemberdayaan Masyarakat. Lestari E, Anantanyu S dan Saddhono K, ed. Surakarta (ID): Fakultas Pertanian UNS dan UNS Press

Oroh. GS. 2014. Peranan Pemerintah Desa Dalam Pemberdayaan Masyarakat d iBidang Pertanian di Desa Tumaratas Kecamatan Langowan Barat Kabupaten Minahasa. Jurnal Politico [internet]. [diunduh 2017 Des 19]; 1(5). Tersedia pada: https://ejournal.unsrat.ac.id/index.php/politico/article/view/6723

Priyanto MA. 2018. "Petani Brebes Demo dan Sebar Bawang Merah Didepan Bulog". http://jateng.tribunnews.com/amp/2018/01/12/petani-brebes-demo-dan-sebar-bawangmerah-di-depan-bulog, 9 maret 2018, pukul 01.48 wib.

Sartono S, Wenni SS dan Wahyuandari. 2014. Analisis Pertumbuhan Kewirausahaan dan Efektifitas Kelembagaan di Kabupaten Tulungagung. Jurnal Universitas Tulungagung Bonorowo [internet]. [diunduh 2017 Nov 24]; 2(1): 596-605. Tersedia pada: http://download.po

rtalgaruda.org/article.php?article $=419079 \& v a l=8951 \&$ title $=$ ANALISIS\% 20 PERTUMBU HAN\%20KEWIRAUSAHAAN\%20DAN\%20EFEKTIFITAS\%20KELEMBAGAAN\%2 0\%20DI\%20KABUPATEN\%20TULUNGAGUNG

Sulistyati M, Herlina L dan Nurachma S. 2011. Dampak proses pemberdayaan terhadap proses keberdayaan peternak domba. Jurnal Ilmu Ternak [internet]. [diunduh 2018 Feb 22]; 11(2): 92-97. Tersedia pada: http://id.portalgaruda.org/?ref=browse\&mod=viewarticle\&article $=23404$

Sumodiningrat G. 1999. Pemberdayaan Masyarakat dan Jaring Pengaman Sosial. Jakarta (ID): PT. Gramedia Pustaka Utama.

Tahir MI. 2017. Model efektivitas organisasi pemerintah desa. Sosiohumaniora [internet]. [diunduh 2018Agu 18]; 19(3): 233-237. Tersedia pada: http://jurnal.unpad.ac.id/sosiohumaniora/article/view/13070/pdf

Usman H dan Akbar PS. 2006. Pengantar Statistika. Jakarta(ID): PT Bumi Aksara. 
Ulumiyah I, Gani AJA dan Mindarti LI. 2014. Peran pemerintah desa dalam memberdayakan masyarakat desa (studi pada Desa Sumberpasir Kecamatan Pakis Kabupaten Malang). Jurnal Administrasi Publik (JAP) [internet]. [diunduh 2017 Sep 25]; 1(5): 890-899. Tersedia pada: https://media.neliti.com/media/publications/74778-ID-peran-pemerintahdesa-dalam-memberdayaka.pdf

Widodo KH, Rembulan D. 2010. Basic Supply Chain Bawang Merah (Allium ascalonicum L) di Kabupaten Bantul Daerah Istimewa Yogyakarta dari Perspektif Sistem Dinamis. INASEA[internet]. [diunduh 2018 Mar 05];11(2): 87-95. Tersedia pada: https://id.portalgaruda.org/?ref=browse $\&$ mod=viewarticle $\&$ article $=165105$ 